Portland State University

PDXScholar

6-16-2021

\title{
Constructing a Contemporary Mythology: Zardulu's Viral Art in the Post-Truth Age
}

Grace Wolfe

Portland State University

Follow this and additional works at: https://pdxscholar.library.pdx.edu/honorstheses

Part of the Contemporary Art Commons

Let us know how access to this document benefits you.

\section{Recommended Citation}

Wolfe, Grace, "Constructing a Contemporary Mythology: Zardulu's Viral Art in the Post-Truth Age" (2021). University Honors Theses. Paper 1048.

https://doi.org/10.15760/honors.1074

This Thesis is brought to you for free and open access. It has been accepted for inclusion in University Honors Theses by an authorized administrator of PDXScholar. Please contact us if we can make this document more accessible: pdxscholar@pdx.edu. 
Constructing a Contemporary Mythology:

Zardulu's Viral Art in the Post-Truth Age

by

\title{
Grace Wolfe
}

An undergraduate honors thesis submitted in partial fulfillment of the

\author{
requirements for the degree of \\ Bachelor of Arts \\ in \\ University Honors \\ and \\ Art History
}

Thesis Adviser

Alberto McKelligan-Hernández

Portland State University 


\section{Acknowledgements}

To Mrs. Andrews, Mr. Bramley, Professor Meir, Professor McKelligan-Hernández, and everyone else who has taken the time to educate me — thank you. Through you I've learned the excitement of critically engaging with history, which is an essential skill to have when the present world overwhelms. There is a beautiful, collectivizing power in properly taught history and I have had the privilege to experience it through all of you.

To my family, my intimate circle of loved ones who never cease to supply warmth and admiration without ever needing a reason. To Aunt Anne and Uncle Matt, for supporting me in every possible way. Your humor, intelligence, and love are endlessly appreciated.

To all of my friends, the funniest most beautiful people to ever exist. I am just so incredibly popular I can't even begin listing all of your names, but know that I wake up every morning and do a little dance for you because I'm so thankful.

To Kurt and Estella in particular. Kurt, thank you for growing up with me and never truly leaving my side even when I moved a whole state away. I cannot wait to live in the same city again. Estella, I could send the most long winded text, or I could just thank you right here in my thesis for everything you are. Thank you for helping me with this thesis, thank you for always being there, thank you for being my friend.

And finally, to the women who raised me:

To my nanna, for instilling me a connection to the universals of spirituality. I can never feel too lost in this world having your supernal love.

And to my mamma. Everything I have, everything I am, is because of you. You have given me an outlook life that can only be rivaled by the best of mythologies. I love you mamma, thank you so much. 


\begin{abstract}
This thesis analyzes the artistic processes of Zardulu the Mythmaker, an anonymous internet figure whose viral art expands upon the language of online hoaxes and media sensationalism to create mythologies that encapsulate the present. Recent scholarship has proposed a shift away from "the contemporary" in art, as its constant efforts toward innovation and detachment from discipline perpetuates the current culture of anxiety. Zardulu's art practice offers a unique separation from the boundaries of contemporary art, which is examined in this thesis through her use of ancient myth-making techniques and the medium of internet virality. Furthermore, this thesis presents Zardulu's methodology as a means of re-orienting the anxieties of the post-truth age and connecting to a collective human experience that has been obscured by the absolutes of the contemporary.
\end{abstract}




\section{Introduction}

On September 21, 2015, a video of a rat carrying a slice of pizza in a Manhattan subway station became an overnight phenomenon. Gaining over two million views within 24 hours, the viral sensation — now known as "Pizza Rat" — quickly became a meme and news story across social media. The public's fascination with Pizza Rat (fig. 1) exhibited a common quest for images of nature reflecting human society. It's a rather silly scene; a rat becomes caught up in the same subway station rush as the humans around him, his sole determination to carry his lunch to somewhere quieter. Pizza Rat therein became an emblem for American perseverance and a figurehead of the New Yorker identity, the top comments on the original YouTube video reflecting this: “A true New Yorker”... “you all see a rat carrying a Pizza, I see a caring father bringing home dinner for his 4 sons!"1 What could have been simply a comical video had become an American icon, both in its most flippant and serious internet representations. Come March 2016, however, Pizza Rat reflected more about contemporary culture than any Twitter user could conjure.

In a video released on Gothamist's YouTube channel, a masked figure wearing a wizard costume and pink hair revealed Pizza Rat to be a hoax: "I create situations that portray rats possessing human traits as a symbolic acknowledgment of our shadow selves,"2 she says, holding a scepter of a rat ouroboros. After claiming responsibility, she proposes a question:

"Why has this become one of the most prolific videos of our generation?"3 It is this concern that presents itself throughout all of the work made by the figure, an artist called Zardulu. With the

\footnotetext{
${ }^{1}$ Matt Little, "New York City rat taking pizza home on the subway (Pizza RatTM)," YouTube Video, 01:14, September 21, 2015, https://www.youtube.com/watch?v=UPXUG8q4jKU\&feature=emb_title.

${ }^{2}$ Gothamist, "Zardulu Claims Responsibility For Pizza Rat Hoax," YouTube Video, 01:45, March 30, 2016, https://www.youtube.com/watch?v=HrsF0cwG8Vo.

${ }^{3}$ Ibid.
} 
knowledge that Pizza Rat was staged, many viewers were disillusioned. The fantastical idea of a rat acting human is no longer authentic, instead its existence reflecting a continuing cycle of "fake news" and augmented realities that permeate throughout contemporary society. Upon observing Zardulu's work, however, Pizza Rat's influence is not to be viewed with pessimism. Rather, Zardulu is attempting to create wonderment in an era that fears the ingenuine. She begins her Manifesto of Zardulism outlining these intentions: "In their classical sense, myths are dead... however, the same archetypes of our primitive subconscious continue to reaffirm themselves in modern traditions."4 Just as she has repurposed the ouroboros to be a rat, Zardulu's art uses premodern mythological imagery and techniques and reconstitutes them within the language of the $21^{\text {st }}$ century. Considering this methodology, and its role in art world, it is first integral to examine the current discourses surrounding $21^{\text {st }}$ century art that have only recently emerged in the field. In the opening chapter of his book, Industry and Intelligence: Contemporary Art Since 1820, Liam Gillick asserts that the term "contemporary art" is no longer pertinent, as "the contemporary has exceeded the specific of the present." ${ }^{5}$ Gillick introduces the need for a new movement, one he defines as "current art." Gillick's analysis reveals the subjectivity of the contemporary, making it difficult for artists to place themselves within its meaning and create innovative works in its name. This inefficacy of the contemporary had already been simmering in academic circles by 2009, as exhibited in Hal Foster's 'Questionnaire on 'The Contemporary"' in October. In his letter to the editors, Foster presents multiple questions regarding the boundaries of contemporary art, mediated by the same concerns of temporality that

\footnotetext{
${ }^{4}$ Zardulu, Founding and Manifesto of Zardulism, 1.

${ }^{5}$ Liam Gillick, "Contemporary Art Does Not Account for That Which Is Taking Place," In Industry and Intelligence: Contemporary Art Since 1820, (New York: Columbia University Press, 2016), 2.
} 
Gillick explores. In seeking to answer these questions, Foster and the editors perpetuate the contemporary ascription of an "end-of-grand-narratives" 6 that is attempting to simultaneously predict and produce the future. This endeavor, and its continuing lack of resolution, reflects not only fissures within the Western art world, but also the current state of global affairs. It's no wonder scholarship concerning the contemporary frequently employs languages of anxiety. Foster's questionnaire grapples with the inaccessibility of contemporary art's attachment to "the market" and "globalization" amidst aftershocks of the 2008 recession, and Gillick's assertions become even more pressing when understood in the context of a deeply polarized culture that cemented itself during the 2016 Presidential election. The concern of the contemporary within recent years, therein, indicates a dissonance that extends beyond academic texts and into daily life.

How can this be remedied? Gillick proposes a movement away from the discourses of the contemporary entirely, as its implicit pressure to "project into the future, to finish narratives" facilitates a culture of anxiety that is counter-productive. Instead of seeking solutions surrounding the future and the notion of progress, perhaps it better serves to simply present questions without the expectation of receiving an answer.

This distinction is the crux of Zardulu's artistic endeavor. The nature of a hoax, which is the foundational element of Zardulu's internet art, prospers under the presupposition of a sensationalized reaction. Unanswered questions and uncanny configurations compel viewers into distinguishing an event as phenomena, the power of which disables the chance of an objective conclusion. When Zardulu reveals her work to be a hoax - meaning, a staged occurrence — she shatters the mysticism of the event that festered during its reactionary period. Reading Zardulu's

\footnotetext{
${ }^{6}$ Hal Foster, "Questionnaire on 'The Contemporary'," October Magazine 130 (2009): 3-124, 3.

${ }^{7}$ Gillick, "Contemporary Art," 12.
} 
work within the constraints of contemporary art would pervasively classify this practice as absolute. Rather, as an expansion of Gillick's “current art," this thesis understands Zardulu's art not as tests reflective of an irrevocably fractured society, but as a cyclical string of mythologies grounded within the benevolent objective of communal wonderment. Furthermore, through an examination of the myth-making techniques present in Zardulu's work and their application within the medium of the internet, this thesis proposes that Zardulism re-orients the anxieties of the present as a means of connecting to a collective human experience.

\section{The Creation of a Zardulist Myth}

In his 1975 book, Mythography: The Study of Myths and Rituals, William Doty opens with a discussion of the criteria that defines mythology. Doty offers a range of components present throughout mythologies. A myth, for example, can be an aesthetic device, an etiology, or a spiritual expression. ${ }^{8}$ Each distinction operates as a working definition of what constitutions a myth, the multiplicity of its definitions indicating an expanse of possible configurations. Doty presents the creation of individual myths as reliant upon "a collection of many interlocked stories" $"$ rather than a purely isolated composition. The significance of adaptions and abstraction in the creation of mythologies indicate their inextricable dependence on cultural networks. Cultures with seemingly no relation have similar myth themes, ${ }^{10}$ which illustrates the commonalities of human experience.

This natural re-contextualizing process grounds itself within concrete aesthetic expression, both in images and stories. Deeming herself a myth-maker, Zardulu's artistic process

\footnotetext{
${ }^{8}$ William G. Doty, Mythography: The Study of Myths and Rituals (Alabama: University of Alabama Press, 1991), 9.

${ }^{9}$ Ibid., 12.

${ }^{10}$ Ibid., 11.
} 
then follows this established framework. The first phase of a Zardulu myth creation likely begins with the construction of referential concept. For example, her 2017 piece The Usurpation of Ouranos (fig. 2) pulls from the account of Kronos' victory over Ouranos in Hesiod's Theogony. She then abstracts the mythology, making it materially applicable to a contemporary environment. Primarily, this is through the use of short videos created with the language and intention of gaining significant attention on the internet — "going viral." In defining the factors that lead to a viral video, author Nicole Matejic distinguishes that internet users largely seek "the LOLs, the awe factor, the weird-but-true and freaky curiosities of life." 11 These factors can be seen in Zardulu's frequent use of animal subjects in perplexing situations. Furthermore, Zardulu's concepts pull from culturally specific viral stories. Inspired by numerous accounts of iguanas appearing in Floridian's toilets, ${ }^{12}$ the video for The Usurpation of Ouranos shows a man in terror after discovering an iguana rising from his toilet. The man in the video, comedian and drag queen Gio Profera, remarks that he discovered the iguana when the reptile bit his genitals, comically mirroring the moment of Ouranos defeat in Hesiod's myth. The humor and shock of the video, coupled with the use of an established viral occurrence, follows the standards required of an effectively viral video.

Within the last decade, social media virality has become comparable to the role of traditional news media. The interconnectivity of social media provides an immediate platform for an unlimited number of individual voices, which has irrevocably altered the way information is consumed and disseminated. News media is now economically dependent upon social media,

\footnotetext{
${ }^{11}$ Nicole Matejic, Social Media Rules of Engagement: Why your Online Narrative is the Best Weapon During Crisis, (Hoboken, NJ: Wiley, 2015), 107.

${ }^{12}$ Helen Stoilas, "Zardulu behind video of iguana appearing in Miami family's toilet," The Art Newspaper, December 11, 2017, https://www.theartnewspaper.com/news/zardulu-behind-video-ofiguana-appearing-in-miami-family-s-toilet.
} 
functioning as the primary place in which news sources find audiences and information worthy of reporting. ${ }^{13}$ Zardulu's art takes advantage of this precedent. She first creates a piece with the intention of garnering social media virality, which ultimately will lead to its coverage in news media. As such, the efficacy of Zardulu's mythologies rely upon the medium of internet virality and its inclination to perpetuate.

\section{Internet Virality as Myth Perpetuation}

Just as the creation of mythologies are dependent upon a tapestry of previously established stories, the function of mythologies and their continued relevancy is determined by social consensus. Doty asserts that culturally significant myths throughout history are rarely idiosyncratic, but instead reflections of communal perspectives and cultural implications. Mapping the cycle of viral content on the internet, a similar pattern emerges. Social media allows each user to share information amongst various networks instantaneously. Vivian Roese, a media scientist, describes information worth this transference as having a certain degree of shareability: "it is the user, as some sort of private gatekeeper, who decides how newsworthy and shareworthy a piece of information in their newsfeed is." 14 The likelihood of cross-communal interactions increase when more individuals share a piece of information, leading to viral content. Although this connectivity creates its own form of community, the internet is paradoxically isolating. These societal ramifications of the internet's information structures are an essential concern in Zardulu's practice: “[contemporary mythology] is produced with the sole purpose of exploiting

\footnotetext{
${ }^{13}$ Vivian Roese, "You Won't Believe How Co-dependent They Are: Or: Media Hype and the Interaction of News Media, Social Media, and the User," In From Media Hype to Twitter Storm, edited by Vasterman Peter, (Amsterdam: Amsterdam University Press, 2018), 313-32, 314.

${ }^{14}$ Ibid., 315.
} 
us and has stripped our lives of substance." ${ }^{15}$ As such, Zardulu's provocation of sensationalized news media works to separate the communal benefits of mythology from its polarizing effects.

Optimistically, journalism should be able to report unbiased facts and accounts of events reflective of communal voices. In the "post-truth" era - a term that has emerged only within the last decade — this standard becomes complicated. ${ }^{16}$ While a comprehensive examination of the facets that constructed the post-truth era are beyond the scope of this thesis, recent scholarship asserts that the fallibility of human memory creates a predisposition to believe misinformation. ${ }^{17}$ Furthermore, those who have firm ideological positions are more likely to reject dissenting perspectives, which has only become more polarized following Donald Trump's frequent use of the term "fake news" during his presidency. ${ }^{18}$ Considering the structures of fake news and its dependence upon cultural values, a clear distinction between fake news and myth is integral. Myth has become a pejorative term in contemporary Western culture, especially when related to issues surrounding science and politics. One reason for this stems from the shift to rationality during the Enlightenment. Doty argues that myths are no longer considered important, as the empirical sciences now make their pre-modern functions obsolete. In modernity, science and spirituality are now seen as diametrically opposed, while in mythologies they are able to exist cooperatively. Another explanation for contemporary hesitancy is the misconception that myths are inherently deceitful. The use of the word "myth" has become a buzzword to capture narratives that functionally serve to control. Although exploitation and manipulation have been

\footnotetext{
${ }^{15}$ Zardulu, The Founding and Manifesto of Zardulism.

${ }^{16}$ Stephan Lewandowsky, Ullrich K.H. Ecker, John Cook, "Beyond Misinformation: Understanding and Coping with the "Post-Truth" Era," In Journal of Applied Research in Memory and Cognition 6, no. 4 (2017), 354.

${ }^{17}$ Hunt Allcott, Matthew Gentzkow, "Social Media and Fake News in the 2016 Election," Journal of Economic Perspectives 31, no. 2 (2017), 230.

${ }^{18}$ Ibid.
} 
common anxieties throughout history, the constant presence of technology and the internet incites a broader sense of paranoia, which has only been inflamed by the discourse of fake news. Where intentionally controlled misinformation seeks to polarize for individual gain, myths allow the individual to journey away from an isolated perspective and enter a larger collective sphere of possible truths. In the Manifesto of Zardulism, Zardulu makes it clear that this is the root through which myths can be reclaimed. What is then fundamentally required to create a Zardulist myth is an acknowledgement of the systems that have "appropriated themselves the role of storyteller," ${ }^{19}$ followed by a co-option of the methods through which they do so. Through this practice, the perpetuating effects of the post-truth age function as collectivizing phenomena rather than polarizing hoaxes.

\section{Zardulism Applied: Watchmen of Lo}

To better understand this process, it serves to analyze one of Zardulu's projects in relation to its news media response. Zardulu's 2015 piece, Watchmen of Lo (fig. 3), begins much as her other work of this period — with a seemingly unstaged video. A fisherman in a red flannel has just pulled a catfish from New York City's Gowanus Canal. The person filming, Greg Hunter, rushes up to the fisherman: "Some people down there just told me that you got a catfish with three eyes?"20 The camera points down to a gray catfish laying limp on the sidewalk. There is nothing entirely out of the ordinary about the catfish, save for the third "eye" on its forehead that resembles a cloudy marble imbedded into its skin. The video is shaky and brief, its action barely the same level of standalone entertainment as the Pizza Rat video. The initial power of

\footnotetext{
${ }^{19}$ Zardulu, The Founding and Manifesto of Zardulism, 3.

${ }^{20}$ Gothamist, "Three-Eyed Fish," DailyMotion Video, 31:00, November 2015, https://www.dailymotion.com/video/x3cy2lw, 00:06-00:09.
} 
this piece rests instead with the response of the bystanders. Twice during the 31 second long video, Hunter mentions his conversations with a group of people off camera. While the fisherman appears relatively unfazed, Hunter's verbal fascination arises as the voice of the unpictured collective. The bystanders become a chorus, their immediate commentary and quest for answers ensuring media response.

Hunter submitted the video to Gothamist, and on November 8, 2015 an article was released in conjunction to the video claiming that the "putrid toxic waters of the Gowanus Canal spit out some mutant hellspawn determined to seek revenge on humanity for decades of nonstop pollution." ${ }^{21}$ Although mentioning that the fish might not be real, the article then presents two other instances of similar three-eyed fish found in recent years. The article goes so far as to deem the fish "Brooklyn Blinky," referencing a The Simpsons episode in which the characters catch a fish with three eyes due to the area's nuclear pollution. While the Gothamist article is clearly inflammatory, its sentiment plays into widely-known cultural understandings. The Gowanus Canal is one of the most polluted bodies of water in the United States, ${ }^{22}$ and generations of New Yorkers have contributed to a catalogue of urban legends that cement the news story as culturally relevant.

In the virtual exhibit for Zardulu's 2017 gallery debut, “Triconis Aeternis: Rites and Mysteries," each work is presented as a compilation of its news coverage and any subsequent social media reactions. Next to the title of each work is a banner signifying the date and news source on which the hoax was revealed — for the Watchmen of Lo, it was March 2016 on The

\footnotetext{
${ }^{21}$ Ben Yakas, "Video: Man Claims He Caught Three-Eyed Fish In Gowanus Canal," Gothamist, November 8, 2015, https://gothamist.com/food/video-man-claims-he-caught-three-eyed-fish-in-gowanuscanal.

$\frac{\mathrm{ca}}{22}$ Jessica Hester, "Brooklyn's Putrid, Beloved Gowanus Canal Has Been a Horror for Centuries," Atlas Obscura, April 12, 2021, https://www.atlasobscura.com/articles/gowanus-canal-superfund-cleanup.
} 
New York Times. More than a year earlier, however, the NYT published an article detailing the various opinions surrounding the validity of the catfish's presence in the Gowanus Canal. As in the Gothamist story, the article includes the position of biologist: "Everything is wrong here...You'd never find a freshwater bullhead in the saltwater Gowanus Canal." ${ }^{23}$ While this assertion from a local expert may appear absolute, the author's following notation proves otherwise: "[The prior claim] might seem to settle the matter, and an earlier version of this article was written as if it did. But that was before Tuesday, when the man who sent in the video, Greg Hunter, insisted the fish was real." 24 The inclusion of this statement is the fruition of Watchmen of $L o$ as a contemporary myth.

William Righter, a literary critic and mythographic theorist, posits that myths present a "concrete possibility" 25 as a response to humanity's frequent quest for explanation. "Possibility" is a critical word choice; possibility is subjective, mimicking the fluidity of mythological representations. As discussed in previous sections of this thesis, myths take the materiality of the present - societal structures, symbols, common conceptions - and bind them into a narrative that is concretely tied to prior experiences. These narratives are then emboldened by phenomena, as engaging with the unknown supplies a vessel through which there are endless possibilities to examine. In this sense, myths respond to pressing questions with an at times subliminal insertion of more questions. Using Watchmen of Lo as an example, the question of the fish's authenticity is determined as most pressing by the current cultural concern for legitimacy amidst internet

\footnotetext{
${ }^{23}$ Andy Newman, “Tale of Gowanus Canal's Three-Eyed Fish May Be Too Good to Be True,” The New York Times, November 10, 2015, https://www.nytimes.com/2015/11/11/nyregion/tale-of-gowanus-canalsthree-eyed-fish-may-be-too-good-to-be-true.html.

${ }^{24}$ Ibid.

${ }^{25}$ William Righter, Myth and Literature (London: Routledge and Kegan Paul, 1975), 94
} 
hoaxes. Furthermore, the question becomes whether or not the Gowanus Canal is polluted enough to create a mutant fish à la The Simpsons.

Imperatively, the author of the NYT article, Andy Newman, is not presenting misinformation. The angle of his article is to present any significant perspectives concerning the presence of a three-eyed catfish in New York City's most polluted body of water. Perhaps in an earlier draft Newman sought to provide a definitive answer, but in his re-work the focus shifted to the facilitation of further discussion. The article, therefore, does not offer an objective conclusion. Instead, Newman includes a quote from another frequent fisherman at the Gowanus Canal, Vladimir Banjac. Having fished at the canal for more than 25 years, Banjac says, "My friends and I read these stories and we laughed...It's not realistic." ${ }^{26}$ Why place this specific perspective at the end, over one of an expert or eye-witness? Consider the framework of Zardulism and its myth-making effects established earlier in this thesis: mythologies require a multitude of culturally significant factors to ensure their perpetuation. Newman's article understands these factors not under the presupposition of myth-making, but of comprehensive and compelling story-telling. Banjac the Fisherman, whose 25-some years of fishing at the canal gives him authority over the area, plays out as a familiar character among many in a supremely New York City based tale. The circumstantial evidence he provides takes narrative precedent over the assertions of a biologist, just as Hunter's claim of having "touched the fish's third eye"27 destabilizes scientific precedent. These distinctions subconsciously play upon contemporary America's distrust of science and government systems, both of which have been inflamed by the constant ideological pressures of the internet. In choosing to present a multi-faceted account of the three-eyed catfish, Newman negates the hysterical dread felt in the Gothamist article. He

\footnotetext{
${ }^{26}$ Andy Newman, "Tale of Gowanus Canal's Three-Eyed Fish."

${ }^{27}$ Ibid.
} 
offers instead a spread of possibilities, therein acting as an unwittingly astute extension of Zardulu's endeavor to create communal conversation through mythology.

\section{Zardulism as Art Practice}

Zardulu's clear comprehension of mythological systems applies directly to her art practice, both of which rely upon emotional engagement. Constance Grady's Vox article on Zardulu describes her concepts as garnering "an authentic emotional reaction: viral videos, images of animals doing weird things in which we can recognize ourselves." ${ }^{28}$ Zardulu's work then creates and perpetuates contemporary symbols, her use of viral videos grounding them within a seemingly authentic context. When a project is revealed to be a hoax, this does not negate the emotional response that was created during the perpetuation period. Instead, by connecting her work to an act of artistic expression, she opens a discursive space that particularly concerns the emotional effects of socially engaged art. Analyzing Zardulu's work as performance art, which she self-ascribes ${ }^{29}$ further indicates the importance of her myth-making archetype: "what [performance art] has to offer is not accurate representation but rather the complication of readings so that we can discover new questions." ${ }^{30}$ As proven in the reactions of Watchmen of Lo and their similarity to pre-modern mythological structures, the cultural significance of Zardulu's art depends upon its ability to generate communal discourse through an invocation of emotion.

\footnotetext{
${ }^{28}$ Constance Grady, "Where Pizza Rat, Fake News, and Art Collide, There's a Wizard Named Zardulu," Vox. May 31, 2017, https://www.vox.com/culture/2017/4/24/14912316/ zardulu-viral-videosmythmaking-surrealism-pedro-lasch.

${ }^{29}$ Ibid.

${ }^{30}$ Pablo Helguera, Education for Socially Engaged Art: a Materials and Techniques Handbook (New York: Jorge Pinto Books, 2011), 71.
} 
The discursive structures of Zardulu's work are grounded within a long history of subversive art practices. She situates her work as an extension of Surrealism and, more directly, the methods of the organization Situationist International. ${ }^{31}$ The Situationist International emerged from a specific form of post-World War II avant-garde practice that emphasized the political uses of_art over aesthetics. Situationist practice then placed importance on spectacle as a means of counter-revolution in a supremely rational postwar society. In his essay on the practices of the Situationist International, Bolt Rasmussen establishes the organization's eventual detachment from art as an extension of their Marxist philosophies: "art is dead and should be transcended in revolutionary practice." ${ }^{\prime 2}$ The Situationist International's negation of art mirrors that of current discourses in the contemporary art world. In her response to Hal Foster's questionnaire on "The Contemporary," curator Kelly Baum posits that "art is now defined by its dis-identification with the discipline of art." ${ }^{33}$ Contemporary art's distancing from itself, from the institution of art and pitfalls of discipline, seeks to facilitate the arrival of a future that is wholly progressive from its past. This is not the objective of Zardulism; her work reveals the possibilities of the present through a connection to the past. She argues that "the same archetypes of our primitive subconscious continue to reaffirm themselves in modern traditions, ${ }^{, 34}$ and her art practice enables this reconnection. When Zardulu reveals a project to be a hoax, she exposes her practice to the public specifically within the context of performance art. Zardulu's attachment to the discipline of art separates her from the distinctions of contemporary art presented in the

\footnotetext{
${ }^{31}$ Constance Grady, "Where Pizza Rat, Fake News, and Art Collide."

${ }^{32}$ Mikkel Bolt Rasmussen, "Counterrevolution, the Spectacle, and the Situationist Avant-Garde," Social Justice 33, no. 2 (104) (2006): 5-15, 13.

${ }^{33}$ Kelly Baum, "Questionnaire," 95.

${ }^{34}$ Zardulu, The Founding and Manifesto of Zardulism, 2.
} 
October questionnaire. Furthermore, this enables her work to present multiple possibilities for conversation and collaboration that the insular structure of the contemporary doesn't provide.

The previous sections of this thesis have discussed the conception and perpetuation of Zardulu's projects, but her work is only fully realized when it is revealed to be a hoax. It is the breaking of this illusion, not the creation itself, that defines her art. Interestingly, Zardulu's earlier endeavors were not intended to be revealed. In a 2017 interview with Vox, comedian Eric Yearwood recounts his collaboration with Zardulu on Selfie Rat (fig. 4) - a video in which a trained rat takes a seemingly spontaneous selfie on an iPhone. Yearwood claims Zardulu was clear to establish that "there wasn't going to be any sort of revelation at the end of [the project]," ${ }^{35}$ making her later practice of taking credit a cause for analysis. By publicly claiming responsibility for her projects, Zardulu supplies an absolute to what was previously esoteric. As exhibited in the media response towards Watchmen of Lo, viewers are able to suspend disbelief even when presented with empirical evidence to the contrary. A definitive answer could then only arrive from the creator, which is unlikely in traditional mythological structures. Zardulu's earlier refusal to reveal likely considered this factor and adhered more towards her mission of creating tales of wonderment without need for resolution: "Why wake the world from a beautiful dream when the waking world is all so drab?"36 Two avenues then present themselves in the ideation of Zardulu's art: to reveal and not to reveal. Both enable the perpetuation of myth, but the discursive efficacy of revealing a work as hoax — and by extension, art — allows her

\footnotetext{
${ }^{35}$ Grady, "Where Pizza Rat, Fake News, and Art Collide, There's a Wizard Named Zardulu," https://www.vox.com/culture/2017/4/24/14912316/ zardulu-viral-videos-mythmaking-surrealism-pedrolasch.

${ }^{36}$ Abby Ohlheiser, "She staged a viral story. You fell for her hoax. She thinks that's beautiful," The Washington Post, December 14, 2016, https://www.washingtonpost.com/news/theintersect/wp/2016/12/14/she-staged-a-viral-story-you-fell-for-her-hoax-she-thinks-thats-beautiful/.
} 
practice to be replicated. While the power to do so may appear insidious, the specific structures of Zardulism as outlined in this thesis do not serve to enact one ideological progression, nor do they function as inherently "good" or "evil." The primary concern of Zardulism is instead to embrace the communal effects of spectacle, to re-orient the isolating anxieties of the post-truth age into "pearls of merriment" 37 all can enjoy.

\section{Conclusion}

In his catalogue essay accompanying the online exhibition for Zardulu's gallery show, "Triconis Aeternis: Rites and Mysteries," Tim Schneider addresses the concern of "realness" when interacting with Zardulu's work. Zardulu grounds her philosophy in ancient mythological techniques and revolutionary art practices, moving beyond the classification of merely a prankster: "the artist's [intention is] to vault past contemporary hoaxing toward contemporary myth-making." ${ }^{38}$ Schneider's assertion supports the argument examined in this thesis; Zardulu expands upon contemporary anxieties and retranslates them through what she argues to be the highest form of art — myth-making. Zardulu's practice reveals an intrinsic connection between myth and art, one that has been obscured in the assumed absolutes of modernity. Although the emotional efficacy of her work does not rely on the breaking of this illusion, understanding Zardulu's art as a an intentionally subversive act focalizes the mythologies of the present.

In the first section of this thesis, William Doty's explication of mythological systems is used to connect Zardulu's myth-making to a larger historical precedent. Throughout the human experience myths have been "a way of projecting and experiencing out anxieties." 39 Zardulism is

\footnotetext{
${ }^{37}$ Zardulu, The Founding and Manifesto of Zardulism, 10.

${ }^{38}$ Tim Schneider, To Know Zardulu Is to Be Forever Changed, (Transfer Gallery: Brooklyn, NY), http:// transfer.gallery/zardulu/essay.html.

${ }^{39}$ Doty, Mythography: The Study of Myths and Rituals, 24.
} 
an extension of this practice; the current pressures of an increasingly digital existence have facilitated an obsession for "truth." This endeavor has been exploited by ideological pursuits, leading to a culture of polarization and, by extension, widespread isolation. Zardulu's viral stories reframe the mediums through which these forces fester, as "they are drawn from our common experience and our collective unconscious." 40

This thesis' examination of Zardulu's 2015 piece Watchmen of Lo exhibits the communal effects of Zardulu's applied myth-making. Her employment of culturally relevant symbols, themes, and mediums enable a collective storytelling that operate much as the pre-modern mythologies Zardulism bases its practice in. Furthermore, when contextualizing Zardulu's work within artistic discipline, Liam Gillick's assertions of a necessary movement away from the confines of "the contemporary" become actualized. Recent scholarship has defined contemporary art practice as having an almost obsessive concern for the future. This "dominance of projection" 41 perpetuates the isolation and rationality of modernity, which counter-acts its revolutionizing endeavors. What this thesis proposes is a disengagement from the quest for objectives in art. Zardulism hinges upon this claim: "Deep down...we don't care about the truth. We want myth. We want our feelings and emotions to be represented in symbolic forms." 42 Although the symbol of a rat carrying pizza down the stars of a subway station appears detached from any reflections of the human condition, Zardulu's art practice binds itself to the pre-modern efficacies of mythology as a means of reawakening a collective consciousness in the present. Her art seeks to lead the self out of isolation and into a "universe in which others see what is true to

\footnotetext{
${ }^{40}$ Zardulu, Twitter Post, August 14, 2019, 6:14 AM, https://twitter.com/zardulu/status/1161633990983540738.

${ }^{41}$ Gillick, "Contemporary Art," 12.

42 Andy Newman, "From the Artist Behind the Selfie Rat, Meet the Toilet Iguana," The New York Times, November 10, 2017, https:/www.nytimes.com/2017/12/10/arts/zardulu-rat-toilet-iguana-video.html.
} 
them," ${ }^{43}$ continuing a process that has been used throughout mythologies to foster communal healing. In the extreme polarization of the post-truth era, and as the world re-emerges from the isolation of the COVID-19 pandemic, Zardulu's viral art presents endless possibilities for community engagement and escape from the misdirections of "absolute rationality." 44

${ }^{43}$ Doty, Mythography: The Study of Myths and Rituals, 24.

${ }^{44}$ Zardulu, The Founding and Manifesto of Zardulism, 10. 


\section{Bibliography}

Allcott, Hunt and Matthew Gentzkow. "Social Media and Fake News in the 2016 Election.” In Journal of Economic Perspectives 31, no. 2 (2017).

Blume, Jonas. "Exploring the Potentials and Challenges of Virtual Distribution of Contemporary Art.” In Digital Environments: Ethnographic Perspectives Across Global Online and Offline Spaces, edited by Frömming Urte Undine, Köhn Steffen, Fox Samantha, and Terry Mike, 97-116.

Doty, William G. Mythography: The Study of Myths and Rituals. Alabama: University of Alabama Press, 1991.

Duncombe, Stephen. "Does it Work?: The Æffect of Activist Art.” Social Research: An International Quarterly 83, no. 1 (2016): 115-134.

Foster, Hal, Julia Bryan-Wilson, Grant Kester, James Elkins, Miwon Kwon, Joshua Shannon, Richard Meyer, Johanna Burton, Pamela M. Lee, Michelle Kuo, Mark Godfrey, Okwui Enwezor, Anton Vidokle, Chika Okeke-Agulu, Terry Smith, Alexander Alberro, Tim Griffin, Yates Mckee, James Meyer, Vered Maimon, T. J. Demos, Christopher P. Heuer, Matthew Jesse Jackson, Andrew Perchuk, Blake Stimson, Kelly Baum, Rachel Haidu, Juliane Rebentisch, Jaleh Mansoor, Siona Wilson, Judith Rodenbeck, Helen Molesworth, Suzanne Hudson, Isabelle Graw, and Tom Mcdonough. "Questionnaire on 'The Contemporary'." October 130 (2009): 3-124.

Gillick, Liam. "Contemporary Art Does Not Account for That Which Is Taking Place." In Industry and Intelligence: Contemporary Art Since 1820, 1-12. New York: Columbia University Press, 2016. 
"Nostalgia for the Group." In Industry and Intelligence: Contemporary Art Since 1820,

111-16. New York: Columbia University Press, 2016.

Gothamist. "Zardulu Claims Responsibility For Pizza Rat Hoax.” YouTube Video, 01:45. March

30, 2016. https://www.youtube.com/watch?v=HrsF0cwG8Vo.

“Three-Eyed Fish.” DailyMotion Video, 31:00. 2015.

https://www.dailymotion.com/video/x3cy2lw.

Grady, Constance. "Where Pizza Rat, Fake News, and Art Collide, There's a Wizard Named

Zardul." Vox, April 24, 2017. https://www.vox.com/culture/2017/4/24/14912316/zarduluviral-videos-mythmaking-surrealism-pedro-lasch.

Helguera, Pablo. Education for Socially Engaged Art: a Materials and Techniques Handbook. New York: Jorge Pinto Books, 2011.

Hester, Jessica. “Brooklyn’s Putrid, Beloved Gowanus Canal Has Been a Horror for Centuries.” Atlas Obscura, April 12, 2021. https://www.atlasobscura.com/articles/gowanus-canalsuperfund-cleanup.

Lewandowsky, Stephan \& Ecker, Ullrich \& Cook, John. "Beyond Misinformation:

Understanding and Coping with the "Post-Truth" Era." In Journal of Applied Research in Memory and Cognition. 2017.

Little, Matt. "New York City rat taking pizza home on the subway (Pizza RatTM)." YouTube Video, 01:14. September 21, 2015. https://www.youtube.com/watch?v=UPXUG8q4jKU\&feature=emb_title. Zardulu, Founding and Manifesto of Zardulism.

Matejic, Nicole. Social Media Rules of Engagement: Why your Online Narrative is the Best Weapon During Crisis. Hoboken, NJ: Wiley, 2015 
Messman, Lauren. “This Washed-Up Sea Creature Was the Work of Viral Hoaxer Zardulu.” VICE, September 18, 2018. https://www.vice.com/en/article/59apnx/this-washed-up-seacreature-was-the-work-of-viral-hoaxer-zardulu.

Newman, Andy. "From the Artist Behind the Selfie Rat, Meet the Toilet Iguana." The New York Times, November 10, 2017. https://www.nytimes.com/2017/12/10/arts/zardulu-rat-toiletiguana-video.html.

“Tale of Gowanus Canal's Three-Eyed Fish May Be Too Good to Be True." The New

York Times, November 10, 2015. https://www.nytimes.com/2015/11/11/nyregion/tale-ofgowanus-canals-three-eyed-fish-may-be-too-good-to-be-true.html.

Ohlheiser, Abby. "She staged a viral story. You fell for her hoax. She thinks that's beautiful." The Washington Post, December 14, 2016. https://www.washingtonpost.com/news/theintersect/wp/2016/12/14/she-staged-a-viral-story-you-fell-for-her-hoax-she-thinks-thatsbeautiful/.

Rasmussen, Mikkel Bolt. "Counterrevolution, the Spectacle, and the Situationist Avant-Garde." Social Justice 33, no. 2 (104) (2006): 5-15.

Righter, William. Myth and Literature. London: Routledge and Kegan Paul, 1975.

Roese, Vivian. "You Won’t Believe How Co-dependent They Are: Or: Media Hype and the Interaction of News Media, Social Media, and the User." In From Media Hype to Twitter Storm, edited by Vasterman Peter. Amsterdam: Amsterdam University Press, 2018, 31332.

Schneider, Tim. To Know Zardulu Is to Be Forever Changed. Transfer Gallery: Brooklyn, NY. http:// transfer.gallery/zardulu/essay.html. 
Stoilas, Helen. "Zardulu behind video of iguana appearing in Miami family’s toilet." The Art Newspaper, December 11, 2017. https://www.theartnewspaper.com/news/zardulubehind-video-of-iguana-appearing-in-miami-family-s-toilet.

Yakas, Ben. "Video: Man Claims He Caught Three-Eyed Fish In Gowanus Canal.” Gothamist, November 8, 2015. https://gothamist.com/food/video-man-claims-he-caught-three-eyedfish-in-gowanus-canal.

Zardulu the Mythmaker. The Founding and Manifesto of Zardulism. - Twitter Post. December 10, 2019, 8:12 AM.

https://witter.com/zardulu/status/1204433817341173761. Twitter Post. April 24, 2020, 5:38 PM.

https://witter.com/zardulu/status/1253845905134047232 


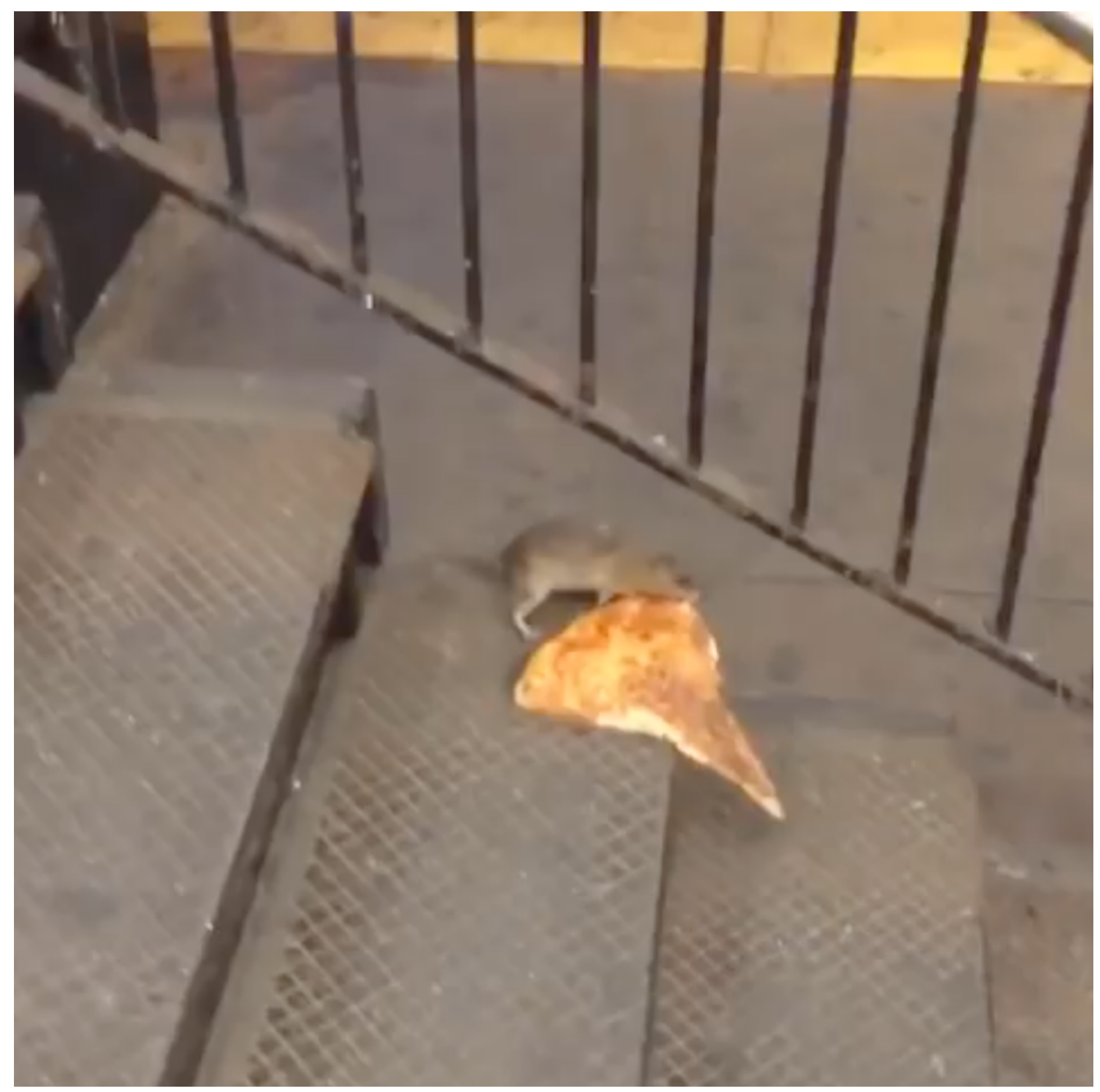

Figure 1. Zardulu the Mythmaker, Pizza Rat, 2015, YouTube video via Matt Little. https:/www.youtube.com/watch?v=UPXUG8q4jKU. 


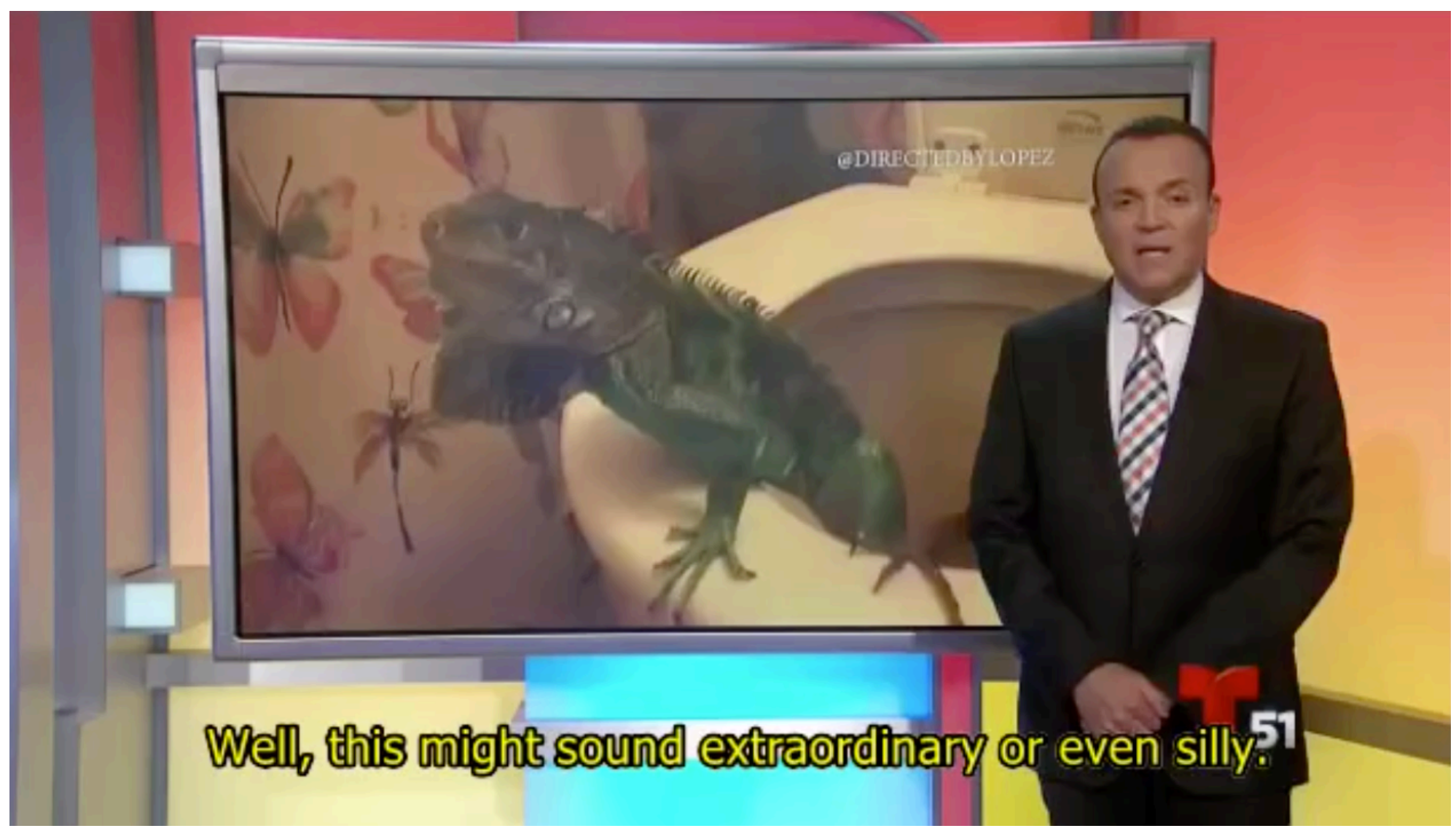

Figure 2. Zardulu the Mythmaker, The Usurption of Ouranos, 2015, YouTube video via Telemundo, https://www.youtube.com/watch? $=2 \mathrm{Xdgr} 4 \mathrm{Tn} 0 \mathrm{z} 0 \& \mathrm{t}=1 \mathrm{~s}$. 


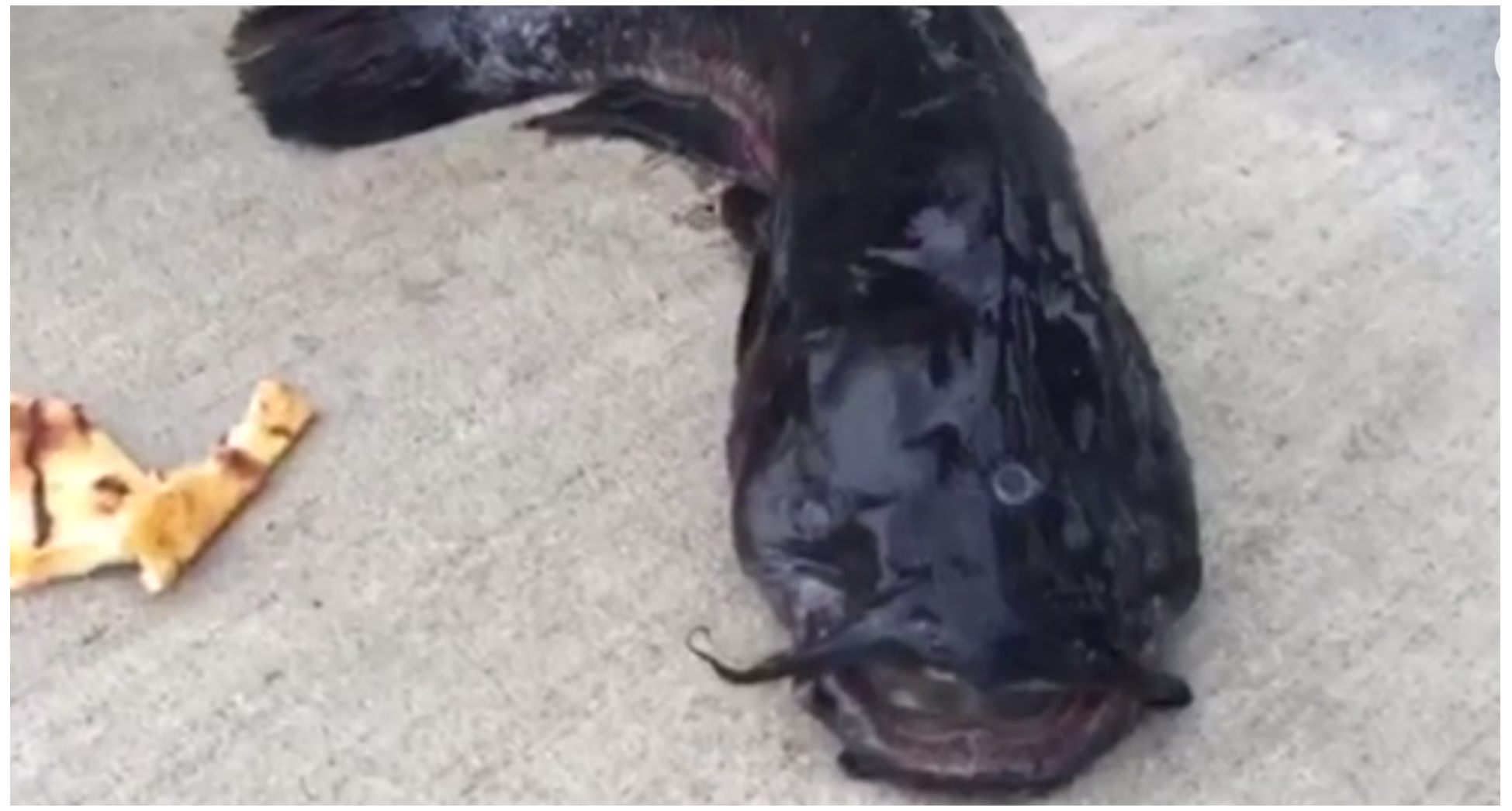

Figure 3. Zardulu the Mythmaker, Watchmen of Lo, 2015, DailyMotion video via Gothamist, Greg Hunter, https://www.dailymotion.com/video/x3cy2lw. 


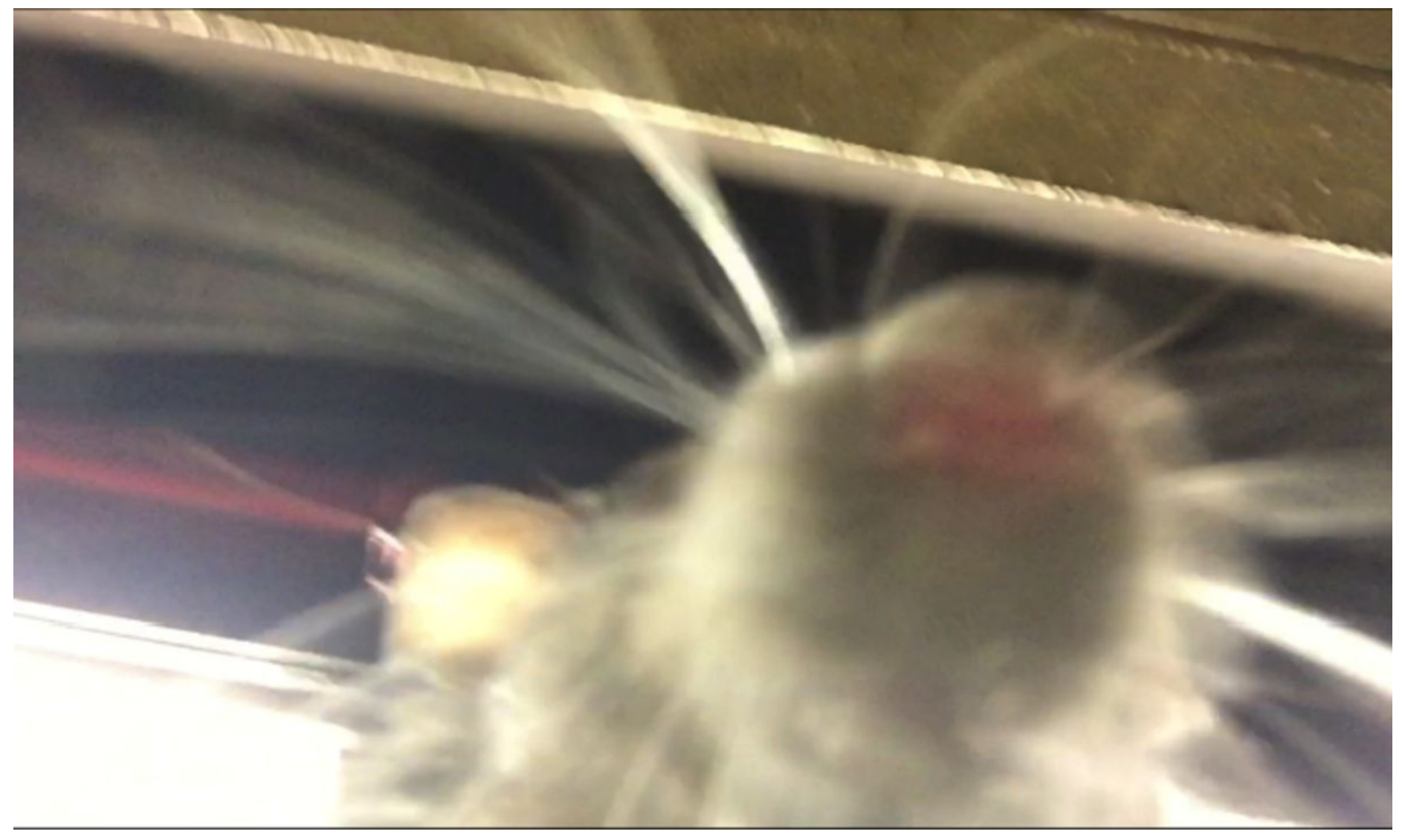

Figure 4. Zardulu the Mythmaker, Selfie Rat, 2015, YouTube video via Don Richards, https://www.youtube.com/watch?v=0SPbKjVIrxg. 